\title{
PELATIHAN ASESMEN MEBACA PERMULAAN BAGI GURU KELAS 1 SD NEGERI SARIJADI BANDUNG
}

\author{
Zulfitrah \\ Pendidikan Luar Biasa, Fakultas Ilmu Pendidikan, Universitas Negeri Makassar
}

Email: zulfitrah@unm.ac.id

\begin{abstract}
Abstrak
Terdapat banyak model pelatihan yang telah diterapkan dalam meningkatkan kemampuan guru, namun pelatihan hendaknya dilakukan berdasarkan kemampuan dan kebutuhan secara alamiah. Penelitian ini menggunakan metode deskriptif dengan pendekatan penelitian yang digunakan adalah kualitatif. Tujuan dari penelitian ini adalah untuk menghasilkan model pelatihan asesmen terkait kemampuan guru dalam mengasesmen peserta didik. Fokus penelitian ini adalah untuk menghasilkan model pelatihan yang alamiah dan sesuai dengan kebutuhan guru di SD Negeri 03 Sarijadi yang meliputi, bagaimanakah pelaksanaan asesmen membaca permulaan yang diterapkan di sekolah, kebutuhan apa saja yang diperlukan dalam pelaksanaan asesmen membaca permulaan di sekolah, bagaimanakah model pelatihan asesmen membaca permulaan bagi guru di sekolah. Pelatihan asesmen membaca permulaan terkait 3 langkah, yaitu: a) Tahap persiapan yang meliputi pemahaman tentang asesmen dan permasalahan dalam membaca permulaan, b) Tahap Pelaksanaan yang meliputi mekanisme pelatihan, strategi/tehnik pelatihan, c) Tahap Evaluasi. Dari hasil penelitian dan pembahasan kemudian disimpulkan bahwa ketidakadaannya model pelatihan asesmen bagi guru yang sesuai dan mampu mengakomodasi kebutuhan guru secara komprehensif sehingga berdampak kepada proses pembelajaran secara langsung seperti sulitnya menentukan kemampuan, hambatan dan kebutuhan peserta didik dalam membaca, memberikan evaluasi serta memberikan rekomendasi dan belum adanya alat asesmen yang bisa dijadikan pedoman oleh guru dan sekolah dalam mengasesmen peserta didik.
\end{abstract}

Kata Kunci : Pelatihan, Asesmen, Membaca permulaan

\section{PENDAHULUAN}

Pada hakekatnya setiap individu maupun kelompok selalu dituntut untuk meningkatkan kemampuannya melalui proses belajar sehingga terjadi perubahan pada dirinya sendiri yang dinamis dan relatif lama. Hubungannya dengan dunia pendidikan, guru memiliki tugas dan andil dalam meningkatkan kemampuannya. Namun tidak semua guru memiliki kemampuan untuk mengembangkan dirinya dengan baik terhadap metode-metode yang dimilikinya dan mengaplikasikannya sesuai dengan kebutuhan dan kemampuannya. Hal tersebut berkaitan dengan kemampuan guru yang belum dioptimalkan dengan baik. Berkaitan dengan kemampuan guru, salah satu kemampuan yang paling penting adalah berkaitan dengan pemahamannya tentang asesmen secara utuh masih kurang sehingga guru perlu mendapatkan pelatihan agar dapat melaksanakan tugas pokoknya dengan efektif dan efisien.

Untuk meningkatkan kemampuan guru dalam melakukan asesmen, dibutuhkan suatu model pelatihan yang tepat sesuai dengan suasana kerja mereka sebagai guru. Pelatihan pada prinsipnya sangat situasional sifatnya. Artinya dengan penekanan pada suasana dan kebutuhan yang alamiah. 
Penggunaan prinsip-prinsip belajar dan alamiah akan berbeda intensitasnya, sehingga benar-benar nyata dengan dunianya. Banyak ahli berpendapat tentang arti, tujuan dan manfaat pelatihan, namun dari berbagai pendapat tersebut pada prinsipnya tidak jauh berbeda. Merujuk pada Inpres Nomor 15 tahun 1974 tentang Pelaksanaan Keppres Nomor 34 tahun 1972: "Pelatihan adalah bagian dari pendidikan yang menyangkut proses belajar untuk memperoleh dan meningkatkan keterampilan diluar sistem pendidikan yang berlaku, dalam waktu yang relatif singkat dan metodenya mengutamakan praktek daripada teori”. Pelatihan yang diberikan kepada guru merupakan salah satu kegiatan yang dapat menfasilitasi kebutuhan guru dalam meningkatkan kemampuannya. menurut Pedler, Burgoyne and Boydell dalam Bintoro dan Daryanto (31: 2014): “A Learning Organization is one which facilitates the learning of all its member and continuously transform itself to achieve superior competitive performance (Learning Organization).

Asesmen merupakan suatu proses pengumpulan informasi secara komprehensif melalui berbagai alat/metode untuk memahami kemampuan, hambatan serta kebutuhan anak yang diperlukan sebagai bahan pertimbangan dalam merencanakan program perkembangan dan pembelajaran yang sesuai. Asesmen banyak digunakan dalam bidang kerja profesional, demikian halnya dengan makna asesmen dalam pendidikan yang berarti untuk menentukan kemampuan, hambatan dan kebutuhan anak secara obyektif untuk menentukan strategi pembelajaran yang tepat. Sebagaimana yang diungkapkan oleh Learner dalam Mulyono (2003), yang dimaksud dengan asesmen adalah "Asesmen adalah proses sistematis dalam mengumpulkan data seorang anak. Asesmen adalah suatu suatu proses pengumpulan informasi tentang anak yang akan digunakan untuk membuat pertimbangan dan keputusan yang berhubungan dengan anak tersebut”. Oleh karena itu kedudukan asesmen sangat penting, karena hal ini sangat berkaitan jelas dengan terwujudnya program pembelajaran yang disusun berdasarkan kemampuan, hambatan dan kebutuhan setiap siswa di sekolah. Keberagaman siswa ini menjadi patokan guru dalam mewujudkan layanan pembelajaran yang sesuai dengan kemampuan/potensinya. Oleh karena itu, guru dituntut untuk memiliki keterampilan dalam melakukan asesmen. Asesmen membaca adalah suatu proses dalam memperoleh data tentang seseorang siswa dalam melakukan aktivitas membaca, baik dalam hal ketepatan membaca maupun dalam memahami isi teks yang dibacanya, sebagai bahan bagi guru dalam menentukan program pembelajaran. Dikemukakan juga oleh Endang Rohyadi (2012), bahwa asesmen membaca adalah suatu proses 
di dalam memperoleh data tentang keterampilan membaca yang telah dicapai dan hambatan yang dihadapi siswa saat ini. Sehubungan dengan itu, maka fokus penelitian ini adalah "Bagaimanakah Model Pelatihan Asesmen Membaca Permulaan Bagi Guru Kelas 1 Sekolah Dasar Negeri 3 Sarijadi Bandung?”

\section{METODE}

Tujuan dari penelitian ini adalah untuk membuat sistematis, faktual dan akurat mengenai fakta-fakta, sifat-sifat serta hubungan antar fenomena yang diselidiki. Pendekatan penelitian yang digunakan adalah pendekatan kualitatif. menurut Sugiyono (2008: 13) penelitian kualitatif adalah metode yang digunakan untuk meneliti pada kondisi objek alamiah. Metode ini bermaksud untuk mendapatkan data penelitian yang lebih komprehensif. Penelitian ini berupaya mengungkapkan model pelatihan asesmen membaca permulaan bagi guru kelas 1 di SDN 03 Sarijadi Bandung.

Berdasarkan pengertian di atas, maka penelitian ini berupaya menghasilkan suatu produk berupa model pelatihan asesmen membaca permulaan bagi guru kelas 1 di Sekolah Dasar Negeri 03 Sarijadi Bandung sebagai salah satu sekolah penyelenggara pendidikan inklusif. Teknik pengumpulan data adalah teknik yang digunakan peneliti untuk memperoleh data yang akan digunakan untuk menjawab pertanyaan dalam penelitian ini. Maka peneliti menggunakan tiga teknik pengumpulan data, yaitu: observasi, wawancara, dan dokumentasi.

Lebih jelasnya dapat dijelaskan sebagai berikut:

1. Observasi

Observasi ini dilakukan dengan tujuan untuk melihat dan mendapatkan data real pada situasi yang peneliti perlukan. Observasi menurut Marshall (dalam Sugiyono, 226, hlm. 2011) menyatakan bawa "trough observation, the researcher learn about behavior and the meaning attached to those behavior" berarti, melalui observasi, peneliti belajar tentang prilaku, dan makna prilaku tersebut. Observasi yang dilakukan pada penelitian ini yaitu observasi nonpartisipan, karena peneliti tidak terlibat langsung dalam aktivitas responden yang peneliti amati. Jenis observasi yang digunakan adalah observasi jenis terstruktur, sebagaimana yang dimukakan oleh Sugiyono (146, hlm. 2011) "observasi terstruktur adalah observasi yang telah dirancang secara sitematis, tentang apa yang akan diamati, kapan dan dimana tempatnya”. Jenis observasi ini digunakan peneliti untuk mengungkapkan secara jelas dan fokus terkait dengan model 
pelatihan asesmen membaca permulaan bagi Guru kelas 1 di SDN 03 Sarijadi Bandung (pedoman terlampir).

2. Wawancara

Wawancara merupakan proses pencarian data dan proses mendapatkan data berupa pendapat responden berdasarkan pengetahuan dan pengalaman responden yang akan digunakan sebagai bahan kajian penelitian. Teknik wawancara yang digunakan dalam penelitian ini adalah dengan menggunakan wawancara semi terstruktur. Menurut sugiyono (2011, hlm. 233) bahwa jenis wawancara ini sudah termasuk dalam kategori in-dept interview, dimana dalam pelaksanaannya lebih bebas bila dibandingkan dengan

wawancara terstruktur. Tujuan wawancara jenis ini adalah untuk menemukan permasalahan secara lebih terbuka, dimana pihak yang diajak peneliti perlu mendengarkan secara teliti dan mencatat apa yang dikemukakan oleh informan/reponden. Wawancara yang dilakukan dalam penelitian ini dilakukan kepada 3 orang Guru SDN 03 Sarijadi Bandung dari tiga rombongan belajar pada kelas 1 . (pedoman terlampir)

3. Dokumentasi
Sugiyono (2012, hlm. 329) "Dokumen merupakan cacatan peristiwa yang sudah berlalu. Dokumen bias berbentuk tulisan, gambar, atau kareyakarya monumental dari seseorang”. Dokumentasi digunakan untuk mengumpulkan data yang berkaitan dengan alat asesmen yang dilakukan guru serta dokumen-dokumen lainnya yang berkaitan dengan pertanyaan penelitian.

Desain Penelitian yang digunakan dalam penelitian ini adalah desain triangulasi dengan tujuan untuk mendapatkan data, penelitian ini diawali dengan observasi kepada guru terkait kisi-kisi instrumen pelaksanaan asesmen membaca permulaan. pada proses ini kemudian dilanjutkan dengan pengumpulan data dengan cara wawancara kepada guru dan melakukan studi dokumentasi oleh peneliti kepada seluruh guru kelas 1 dari SDN 03 Sarijadi Bandung, yang bertujuan memperoleh melengkapi gambaran yang jelas dan terfokus terhadap kemampuan guru dalam melakukan asesmen membaca permulaan. Untuk lebih jelasnya maka divisualisasikan melalui desain penelitian sebagai berikut: 


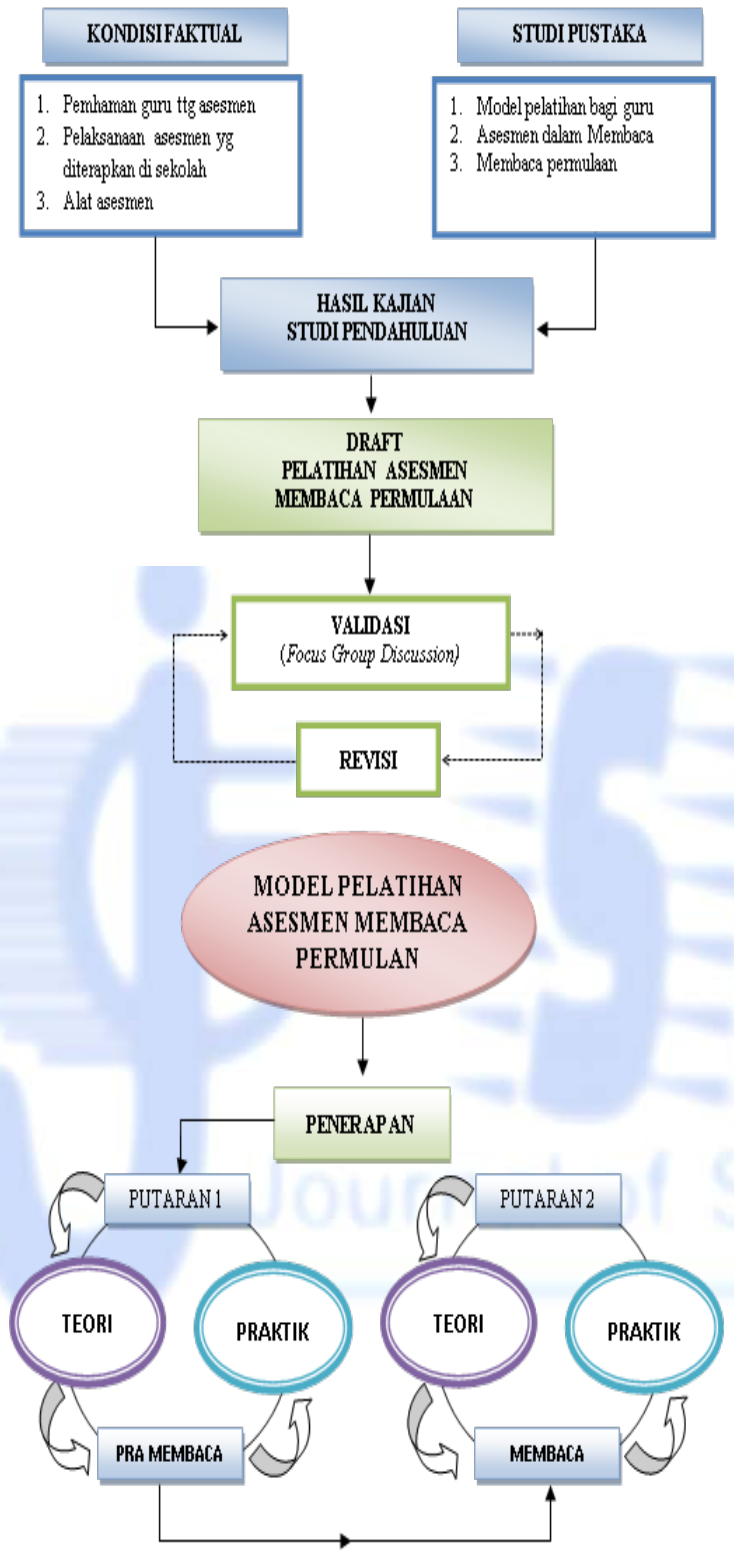

Gambar 1. desain penelitian

Analisis data pada tahap ini dilakukan melalui langkah-langkah sebagai berikut:

a. Reduksi data adalah mereduksi data berdasarkan permasalahan penelitian. Dengan demikian, tujuan mereduksi data akan mempermudah peneliti untuk mengumpulkan data yang berupa hasil observasi, wawancara dan data hasil studi dokumentasi. Kemudian data tersebut akan dipaparkan dalam bentuk deskriptif.

b. Display data atau penyajian data bertujuan untuk menyimpulkan data hasil wawancara kepada guru kelas 1 melalui teks yang bersifat naratif, kemudian melakukan perencanaan kegiatan selanjutnya berdasarkan apa yang dipahami oleh peneliti terkait model pelatihan asesmen membaca permulaan.

c. Verifikasi data bertujuan untuk menganalisis data dengan cara menarik kesimpulan dan memverifikasi data hasil wawancara tentang model pelatihan asesmen membaca permulaan berdasarkan tujuan penelitian. Sehingga kesimpulan tersebut dapat ditentukan model pelatihan yang strategis dalam melaksanakan asesmen membaca permulaan bagi guru.

Adapun skema analisis data yang akan digunakan dalam penelitian ini adalah sebagai berikut:

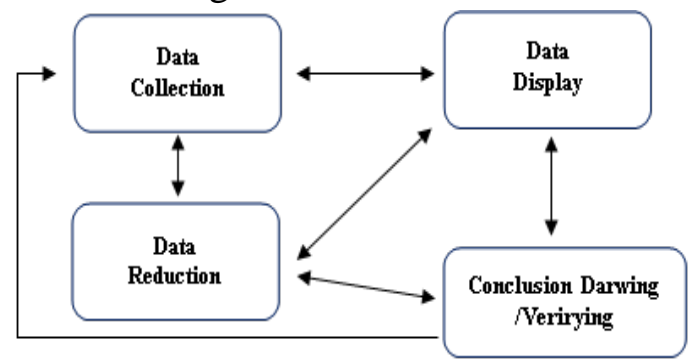


Gambar 2. langkah-langkah analisis data Kualitatif (Miles dan Huberman, 1984, hlm. 16).

\section{HASIL DAN PEMBAHASAN}

Hasil penelitian ini memiliki tujuan akhir yaitu tersusunnya panduan model pelatihan asesmen membaca permulaan bagi guru kelas 1 SDN 03 Sarijadi Bandung. Data yang dibutuhkan dalam menyusun model pelatihan asesmen tersebut adalah mengetahui bagaimana pelaksanaan asemen membaca permulaan yang diterapkan disekolah yakni: terkait tentang pelaksanaan asesmen membaca permulaan yang diterapkan di sekolah selama ini, memahami kebutuhan apa saja yang diperlukan dalam pelaksanaan asesmen membaca permulaan di sekolah, dan model pelatihan asesmen membaca permulaan bagi guru di sekolah yang divalidasi melalui kegiatan Focus Group Discussion (FGD).

Informasi tentang subyek penelitian di SD Negeri 03 Sarijadi Bandung, bahwa subyek terdiri dari 3 guru kelas 1. Data diperoleh peneliti melalui observasi, wawancara, dan studi dokumentasi. kemudian dideskripsikan dan dikelompokkan secara sistematis berdasarkan fokus masalah dan subjek penelitian, agar memudahkan pembaca dalam memahami penelitian ini. Selanjutmya hasil penelitian ini akan diuraikan sebagai berikut:

1. Pelaksanaan asesmen membaca permulaan di sekolah sebagai kondisi obyektif/alamiah guru di
Sekolah Dasar Negeri 03

Sarijadi Bandung. Pada penelitian ini menunjukkan kondisi obyektif kemampuan guru yang sesungguhnya dalam melakukan asesmen membaca pada murid kelas 1, unsur-unsur yang terkait dengan pelaksanaan asesmen di sekolah merupakan indikator keberhasilan pelaksanaan asesmen yang dilakukan oleh 3 responden guru kelas 1 dan dapat diungkapakan sebagai berikut:

a. Proses identifikasi Identifikasi dalam asesmen dilakukan dengan proses menemukan dan mengenali peserta didik dengan cara melihat hasil kerja tugas, wawancara orang tua, teman dan peserta didik itu sendiri. Yang peniliti dapatkan adalah guru belum melakukan proses identifikasi dengan baik.

b. Proses asesmen (screening) Pada proses screening yang dimaksud oleh peneliti adalah proses guru melakukan penyaringan dan pengelompokan peserta didik yang mampu membaca permulaan dengan peserta didik yang memiliki hambata dalam membaca permulaan. Hasil penelitian yang didapatkan adalah belum terjadi prose 
screening yang secara runut, akurat dan tersistematis. Yang peneliti dapatkan adalah guru melakukan asesmen secara klasikal dengan menuliskan 1 kata di papan tulis, kemudian dipecah menjadi suku kata dan dan dipecah menjadi huruf, kemudian guru menunjukkan kata, suku kata dan huruf dan anak menjawab secara klasikal, Sehingga hasil asesmen yang didapatkan oleh guru belum komprehensif.

c. Evaluasi asesmen penelitian menunjukkan belum adanya proses evaluasi yang dilakukan oleh guru, hal tersebut disebabkan oleh belum adanya alat asesmen yang dijadikan pedoman pelaksanaan asesmen membaca permulaan di sekolah. Pada tahap evaluasi ini, peneliti mendapatkan bahwa guru melakukan evaluai berdasarkan pengalaman yang telah ada, hal tersebut tidak menjadi salah namun pada penentuan hasil akhir dari proses asesmen yang dilakukan oleh guru di sekolah belum baik dan tidak didokumentaikan dengan baik.
2. Hal yang dibutuhkan dalam merumuskan pelatihan asesmen membaca permulaan di sekolah. Berdasarkan hasil penelitian, didapatkan dalam pelaksanaan asesmen membaca permulaan yang dilakukan di sekolah menunjukkan bahwa pelasksanaan asesmen membaca permulaan selama ini hanya dengan menuliskan kata, suku kata dan huruf di papan tulis dan meminta murid membaca secara klasikal saja, hal tersebut terjadi karena disebabkan belum adanya panduan pelaksanaan asesmen yang dijadikan patokan dalam menilai kemampuan, hambatan dan kebutuhan membaca permulaan peserta didik. Guru pernah mengikuti pelatihan asesmen namun guru merasa belum memenuhi kebutuhan guru berdasarkan permasalahan yang terjadi di kelas yang diampu sehingga dipandang pelatihan yang diikuti belum dapat memberikan solusi permasalahan guru melakukan asesmen kepada peserta didik. Guru juga mengharapkan alat asesmen yang praktis dan menggunakan bahasa yang mudah dimengerti dan tidak menggunakan bahasa yang akademis semata. Dalam hal ini peneliti ingin membantu membuat atau merumuskan model pelatihan dalam 
melakukan asesmen membaca permulaan di sekolah, sehingga bisa membantu guru dalam melakukan asesmen pada kelas yang diampunya. Namun sebelum membuat model pelatihan terlebih dahulu peneliti ingin mengetahui terlebih dahulu apa saja yang dibutuhkan oleh SDN 03 Sarijadi bandung. Melalui wawancara dan studi dokumentasi.

3. Model Pelatihan asesmen membaca permulaan bagi guru kelas 1 SD Negeri 03 Sarijadi Bandung

a. Draf model pelatihan asesmen membaca permulaan bagi guru kelas 1 SD Negeri 03 Sarijadi Bandung. Model pelatihan pengembangan ini dirumuskan berdasarkan hasil studi kualitatif di lapangan. Temuan pada SD Negeri $03 \quad$ Sarijadi menunjukkan sekolah belum memiliki panduan pelaksanaan asesmen membaca permulaan yang dapat diterapkan oleh guru, hal tersebut ditunjukkan guru hanya memiliki lembar penilaian mambaca yang belum terstruktur dan belum mamadai untuk mengungkapkan kemampuan, hambatan dak kebutuhan anak dalam membaca permulaan. Oleh larena itu peneliti merancang draf model pelatihan asesmen membaca permulan ini karena sesuai dengan kondisi faktual dan kebutuhan guru. Pemahaman akan konsep dasar pendidikan inkulif oleh setiap peserta pelatihan bermanfat dalam pelaksanaan tugas di lapangan. Hal tersebut sebanding lurus dengan bagaimana cara guru menerjemahkan fenomena yang terjadi di sekolahnya. Sekolah memiliki kewajiban dalam memberikan pembelajaran yang sesuai dengan kemampuan, hambatan dan kebutuhan peserta didik salah satu cara mengetahui kemampuan, hambatan dan kebutuhan peserta didik yakni dengan melakukan pelatihan asesmen yang akurat dan komprehensif bagi guru. Model pelatihan asesmen dilandasi oleh 3 langkah yang wajib dipahami, yaitu: mengidentifikasi, melakukan screening, dan melakukan evaluasi dan rekomendasi. 
Merujuk dari kebutuhan akan pelatihan dan materi pelatihan yang akan dilatihkan kepada guru, pelaksanaan pelatihan yang akan diterapkan untuk melatih guru dalam mengasesmen membaca permulaan peserta didik kelas 1 secara prosedur disusun sebagai berikut:

1) Komponen persiapan dibagi menjadi 3 yakni:

Pada tahap ini intruktur melakukan persiapan materi terkait asesmen membaca permulaan, merumuskan tujuan pada kegiatan penelitian berdasarkan kebutuhan (Training Need Assessment), dan membuat jadwal pertemuan pelatihan agar tugas pokok guru tidak terganggu.

(a) Materi pelatihan disampaikan oleh narasumber tentang asesmen membaca permulaan dan prasyarat membaca, materi tentang membaca permulaan dan prasyarat membaca.

(b) Tujuan pelatihan

(c) Jadwal pelatihan dilakukan di luar jam pelajaran setelah proses PBM selesai dan dibuatkan rundown kegiatan pelatihan.

2) Komponen penerapan dibagi menjadi 3 unsur yakni:

(a) Model/skenario pelatihan dilakukan sesuai dengan kebutuhan guru yaitu adanya masukan dari narasumber, proses pelaksanaan asesmen dan tujuan akhirnya guru dapat memahami pelaksanaan asesmen membaca permulaan dan memiliki keterampilan mengasesmen peserta didik di kelas yang diampu.

(b) Tehnik pelatihan dilakukan dalam lingkungan guru mengajar (on the job traning).

(c) Mekanisme kegiatan pelatihan terdapat 2 kegiatan pelatihan yaitu: 


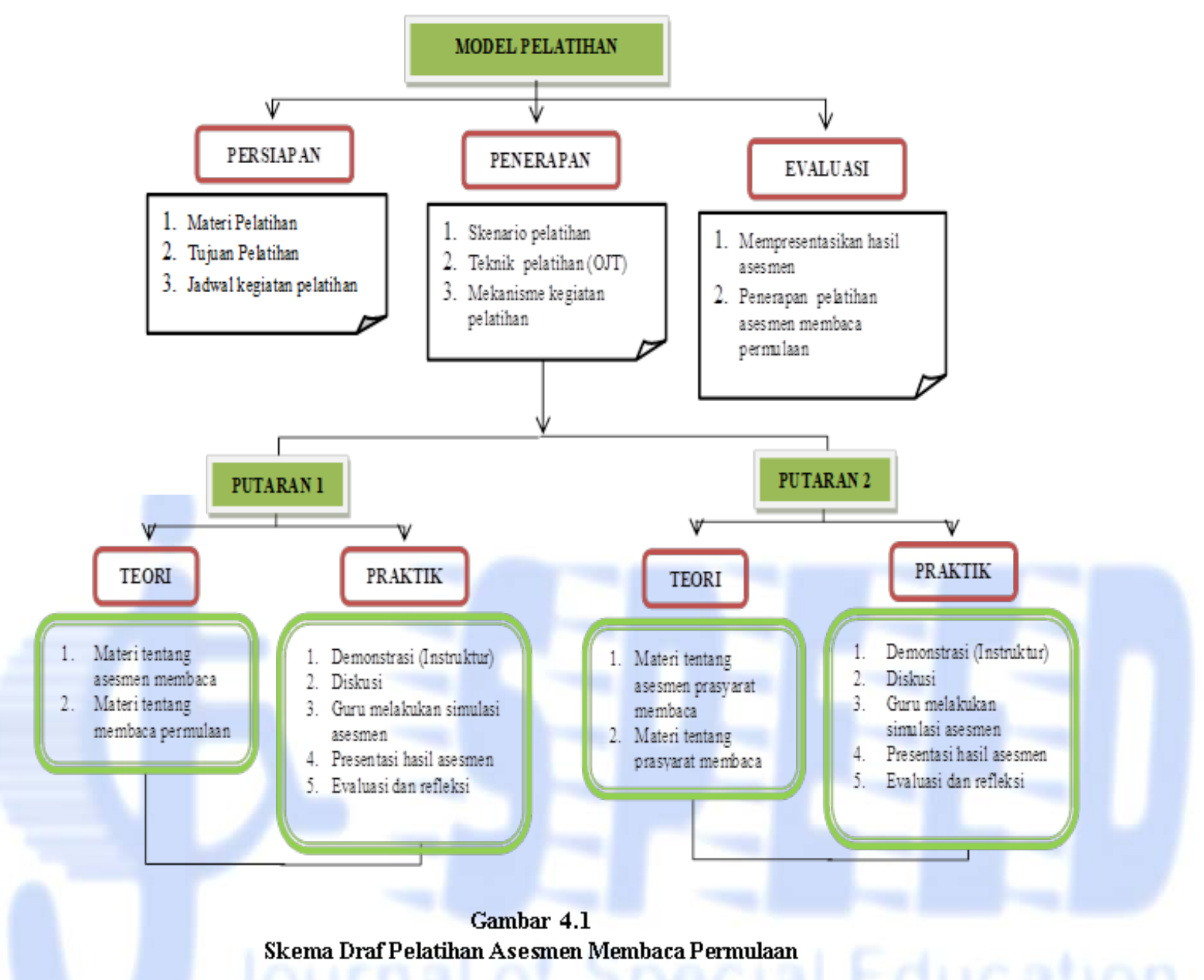

berikut ada deskripsi draft pelatihan asesmen meembaca permulaan: Putaran 1 , pada kegiatan ini mengandung 2 kegiatan yaitu (1) pemberian Materi/teori terkait asesmen membaca permulaan dan materi membaca permulaan, (2) kegiatan praktik dimulai dengan demosntrasi oleh instruktur, diskusi, guru melakukan simulai asesmen, presentas hasl asesmen, evaluai dan refleksi.

Putaran 2, pada kegiatan ini mengandung 2 kegiatan yaitu (1) pemberian materi/teori terkait asesmen prasyarat membaca dan materi prasyarat membaca, (2) kegiatan praktik putaran 2 sama halnya dengan putaran 1 .

Draf model pelatihan asesmen membaca permulaan bagi guru kelas 1 SD Negeri 03 Sarijadi Bandung yang telah divalidasi

Model pelatihan yang dirancang peneliti tidak serta merta langsung dilaksanakan, namun sebelum penerapannya, instruktur terlebih dahulu melakukan Training Need Assessment (TNA), pada tahap ini instruktur melakukan analisis kebutuhan guru terhadap permasalahan yang terjadi pada kondisi alamiah 
peserta pelatihan dengan cara menganalisis kemampuan guru dalam melakukan asesmen dengan melakukan observasi, studi dokumentasi dan wawancara kepada calon peserta pelatihan, kemudian merumuskan tujuan pelatihan, merencakan jenis materi yang akan disampaikan dan membuat jadwal pelatihan dengan pertimbangan tidak menggunakan waktu pembelajaran di sekolah. hal tersebut didukung oleh pendapat Jean Barbazette (2006:140) bahwa di dalam melakukan Training Need Assessment maka perlu melakukan 10 kompetensi rencana oleh tainer yakni: 1) Identifies the training issue and how it relates to a business need, 2) states the outcomes, results and objectives of training, 3) states the performance deficiency and its causes, 4) identifies or establish performance standards, 5) identifies the target population, 6) establishes criteria to evaluate the training, 7) Describes the proposed intervention describes the training event that will meet need in the training plan objectives, 8) Estimates the cost and the training plan lists the anticipated expensives to conduct the training event, 9) build a partnership, 10) Schedules training”.

Pada tahap penerapan dalam model pelatihan ini dilakukan dengan 2 putaran yang dibagi menjadi komponen teori dan praktik dan setiap akhir putaran dilakukan evaluasi terhadap pelaksanaan pelatihan pelatihan putaran 1. Kemudian dilanjutkan dengan putaran ke 2 dengan pembahasan yang berbeda yang dibagi menjadi komponen teori dan komponen praktik kemudian diakhir putaran dilakukan evaluasi terhadap pelaksanaan pelatihan putaran ke dua. Hal ini diasumsikan oleh peneliti sebagai pembeda dengan model pelatihan lainnya dengan menerapkan evaluasi disetiap sesi putaran pelatihan, hal tersebut di indikasikan dapat menjadi solusi bagi intruktur untuk menilai kemampuan peserta dengan detail dan sistematis.

Untuk melihat ketercapaian pelatihan diukur dengan menggunakan standar kompetensi, kompetensi dasar materi pelatihan yang dijadikan sebagai kurikulum pelatihan ini. Tehnik pelatihan yang digunakan adalah On The Job Training, dengan mekasnisme pelatihan yang menekankan kepada kegiatan yang mampu mengungkapkan pemahaman peserta dari segi konsep tentang ruang lingkup membaca permulaan, dan skill/keterampilan paserta melakukan prosedur pelaksanaan asesmen membaca permulaan yang utuh dan mandiri. Metode yang digunakan dalam pelatihan ini yaitu dengan diskusi sebagai unsur pemahaman konsep, demonstrasi/praktik sebagai unsur untuk mengungkapkan kemampuan guru melakukan asesmen membaca permulaan. 


\section{PENUTUP}

\section{Simpulan}

Merujuk kepada hasil penelitian dan pembahasan yang telah diuraikan pada bab sebelumnya tentang kondisi faktual pelaksanaan asesmen membaca permulaan yang ditemukan di lapangan, maka peneliti merumuskan kesimpulan terkait model pelatihan asesmen membaca permulaan di SD Negeri 03 Sarijadi Bandung sebagai berikut:

1. Pelaksanaan asesmen membaca permulaan yang diterapkan guru di SD Negeri 03 Sarijadi Bandung. Berdasarkan hasil penelitian terhadap kondisi faktual pelaksanaan asesmen membaca permulaan bagi guru kelas 1 terkait identifikasi, proses screening, evaluasi dan rekomendasi, maka dapat dijadikan kemampuan guru dalam melakukan asesmnen tersebut. Guru pada dasarnya memiliki kemampuan untuk mengembangkan

kemampuannya dengan optimal dengan melakukan Peer Teaching dan mengikuti pelatihan terkait asesmen, namun hal tersebut belum mampu mengambangkan kemampuannya. Hal tersebut didasarkan karena guru masih belum memahami asesmen secara utuh dan komprehensif, guru belum pernah mengikuti pelatihan asesmen sama sekali, belum adanya pedoman yang dimiliki oleh guru dalam melakukan asesmen membaca, refrensi yang dimiliki oleh guru susah untuk dipahami (bahasa kurang operasional) sehingga guru belum mampu mamahami prosedural dalam melakukan asesmen.

2. Kebutuhan dalam pelaksanaan asesmen membaca permulaan bagi guru kelas 1 SD negeri 03 Sarijadi. Berdasarkan hasil peneltian terhadap kondisi faktual pelaksanan asesmen menunjukkan belum adanya model pelatihan yang mampu menigkatkan kemampuan guru dalam melakukan asesmen, hal tersebut terdapat beberapa indikator keberhasilan, yakni: belum memadainya pelatihan asesmen yang sesuai dengan kondisi alamiah guru dan belum adanya modul asesmen yang komprehensif dan praktis untuk dipahami oleh guru dalam melakukan asesmen membaca permulaan. Kedua hal tersebut merupakan kebutuhan yang paling mendasari keberhasilan asesmen yang diterapkan di sekolah. Sehingga peneliti menyusun sebuah model pelatlihan asesmen membaca permulaan yang didalamnya terdapat komponen-komponen yang dibutuhkan dalam melakukan asesmen membaca permulaan kepada peserta didik 
yaitu dengan memahami anak dengan kebuthan khusus, anak dengan problematikan membaca dan proses melakukan asesmen dimulai dari proses identifikasi, melakukan screening dalam rangka menyaring peserta didika yang memang mengalami hambatan dalam membaca permulaan, dan memberikan penilaian sampai dengan membuat profil anak secara utuh terhadap kemampuan, hambatan dan kebutuhan peserta didik yag diampu dikelas masing-masing.

3. Model pelatihan asesmen membaca permulaan bagi guru kelas 1 SD Negeri Sarijadi yang telah divalidasi melalui Focus Group Discussion (FGD). Penyusunan model pelatihan asesmen membaca permulaan ini bertujuan untuk memberikan masukan yang positif dan bermanfaat bagi guru dalam memberikan layanan kepada peserta didik. Guru mampu memahami pelaksanaan asesmen secara utuh dan komprehensif, memberikan khasanah pemahaman terhadap anak dengan problematika membaca, meningkatkan motivasi guru dalam dalam upaya mengembangkan kemampuan pseserta didik, melayani peserta didik sesuai dengan hambatan dan kebutuhan peserta didik secara sistematis dan terstruktur. Model pelatihan asesmen membaca permulaan ini disusun berdasarkan hasil pemelitian di lapangan yang sudah divalidaai melalui kegiatan Focus Group Discussion (FGD).

\section{Saran}

Berdasarkan hasil penelitian yang didapatkan, maka peneliti dapat merekomendasikan hasil penelitian sebagai berikut:

1. Kepala sekolah

Hasil penelitian ini diharapkan mampu menjadi bahan pertimbangan kepada setiap pimpinan sekolah inklusi untuk menjadikan panduan melakukan pelatihan kepada guru dalam melakukan asesmen membaca permulaan bagi guru di sekolah.

2. Guru

Hasil penelitian ini diharapkan mampu menjadi bahan acuan dan motivasi untuk pengembagan guru dalam memberikan masukan yang positif dalam meningkatkan kemampuannya dalam melakukan asesmen membaca secara komprehensif dan utuh.

3. Dinas pendidikan

Hasil penelitian ini diharapkan mampu memberikan gambaran alamiah terhadap kebutuhan guru dalam melakukan asesmen membaca permulaan, Berhubungan dengan pelatihan 
yang diikuti guru selama ini dan kemampuan guru dalam melaksanakan asesmen membaca permulaan di sekolah lebih ditekankan pada praktek langsung secara berulang-ulang sehingga pengalaman menjadi milik guru secara utuh. Hasil temuan ini dapat direkomendasikan kepada Dinas Pendidikan sebagai penentu kebijakan dalam pengembangan program pelatihan asesmen bagi guru-guru di sekolah inklusi.

\section{DAFTAR PUSTAKA}

Afiatin T, dkk. (2013). Mudah dan Sukses Menyelenggarakan Pelatihan, Melejitkan Potensi Diri. Kanisius:Yogyakarta.

Ahmad, Rofi’uddin. (2001). Pendidikan Bahasa dan Sastra Kelas Tinggi. Malang : Universitas Negeri Malang.

Bintoro dan Daryanto. (2014). Manajemen Pendidikan dan Pelatihan (DIKLAT).Gava Media: Yogyakarta.

Creswell, John W. (2010). Research Design: Pendekatan Kualitatif, Kuantitatif, dan Mixed. Pustaka Pelajar: Yogyakarta.

Granfell M, (1998). Training Teacher In Practice. Multilingual Matters: USA.

Hamzah, Uno, (2012). Assement Pembelajaran. Jakarta: Buma Aksara.

Joseph A. Martin dan Vincent J. Dean. (2009). Innovative Assessment
For The 21st Century, Supporting Educational Needs. USA.

Tim Penulis, (2010). Modul Pelatihan Pendidikan Inklusif. Jakarta: Kementrian Pendidikan Nasional Bersama Kemitraan Australia Indonesia.

Moekijat, (1990), Pengembangan dan Motivasi, Bandung: Pionir Jaya.

Putra N, dan Hendarman. (2013). Mixed Methods Research: Metode Riset Campur Sari Kosep, Strategi,dan Aplikasi.Indeks:Jakarta.

Rahmiyati (2011). Profil Membaca Permulaan Pada Anak Berkesulitan Membaca Di Kelas Satu Sekolah Dasar. Tesis pada jurusan PKKh SPS UPI. Bandung.

Rochyadi E. (2010). Pengaruh Kesadaran Linguistik Dan Kesadaran Persepsi Visual Terhadap Kemampuan Membaca Permulaan Anak Tunagrahita. Desertasi pada jurusan PKKh SPS UPI. Bandung.

Rochyadi E. (2012). Perkuliahan Asesmen Membaca. UPI. Bandung.

Sara B, Salvia J, Ysseldyke J. (2010). Assessment: In Special and Inclusive Education, Eleventh Edition. Wadswoth Cengage Learning. USA

Sarjita. (2011). Model Program Pelatihan Asesmen Membaca

Sumantri, S. (2000), Pelatihan dan Pengembangan Sumber Daya Manusia, Bandung, Fakultas Psikologi Unpad.

Santoso (2011) Profil Anak-Anak Yang Mengalami Hambatan Dalam 
Area Perkembangan Literasi Dini. Tesis pada jurusan PKKh SPS UPI. Bandung.

Santrock, John W. (2001). Perkembangan Anak. Erlangga: Jakarta.

Sugiyono, E. (2012). Metode Penelitian Kuantitatif, Kualitatif dan R\&D. Bandung: CV. Alfabeta.

Tjiptono, F dan Diana, A, (1998), Total Quality, Management, And offset. Yogyakarta.

Universitas Pendidikan Indonesia. (2013). Pedoman Penulisan Karya ilmiah (Laporan, Buku, Makalah, Skripsi, Tesis, Disertasi). UPI: Bandung.

Winihasih. (2009). Diagnosisi Kesulitan Membaca Permulaan Siswa SD/MI Melalui Analisis Reading Readness. Tesis pada jurusan PKKh SPS UPI. Bandung.

Zuhhdi, Darmiyati dan Budiasih. (2001). Pendidikan dan Sastra Kelas Rendah. Universitas Negeri Malang: Malang 